\title{
Immobilization of selected heavy metals from fly ash from thermal treatment of municipal sewage sludge in hardening slurries
}

\author{
Eukasz Szarek $^{1 *}$, Pawel Falaciński ${ }^{1}$, and Matgorzata Wojtkowska ${ }^{1}$ \\ ${ }^{1}$ Warsaw University of Technology, Faculty of Building Services, Hydro and Environmental \\ Engineering, Poland
}

keywords: hardening slurries; fly ash from thermal treatment of municipal sewage sludge; heavy metals; immobilization; microstructure.

\begin{abstract}
The growing number of municipal sewage treatment plants in Poland raises the problem of managing more and more sludge. The thermal treatment of municipal sewage sludge (TTMSS), which significantly reduces the volume of waste, results in an increase in the concentration of heavy metals in the fly ashes - the final products of the process. The search for methods of utilization of fly ash from TTMSS resulted in attempts to use it in hardening slurries widely used in hydro-engineering. Due to the nature of the application of this material in the cut-off walls (exposure to groundwater flow) one of the key issues is the degree of heavy metal immobilization. The paper attempted to determine the degree of leaching of selected heavy metals from the hardened hardening slurry, composed of fly ash from TTMSS. For this purpose, the eluates were prepared from samples, after various periods of curing, using a dynamic short-term method called "Batch test". The liquid used for leaching was: distilled water and 0.1 molar EDTA solution to determine the amount of potentially mobile heavy metal forms. The results show the possibility of the safe usage of fly ash from TTMSS as an additive for hardening slurries.
\end{abstract}

\footnotetext{
*Corresponding author: lukasz.szarek@pw.edu.pl
} 


\section{Introduction}

As a result of the increasing use of thermal treatment of municipal sewage sludge (TTMSS) in Poland (from approx. $1 \%$ of generated sewage sludge in 2008 to approx. $15 \%$ in 2014 [1]), a problem related to management of fly ashes resulting from this process occurred. The resulted situation constitutes an incentive to look for the ways of using fly ashes from thermal treatment of municipal sewage sludge (TTMSS), so that according to the Circular Economy idea they are a fully valuable product, ready for use.

The ash generated as a result of sewage sludge incineration is characterised by, among others, a high water demand, low hydraulic and pozzolanic activities [2, 3], and a significant phosphorus content [4]. In addition, as a consequence of the municipal sewage sludge incineration and the related concentration of components, the ashes show an increased content of some heavy metals [5].

One of the ways of managing the growing amounts of fly ashes from thermal treatment of municipal sewage sludge is their use in hardening slurries [2], in which other combustion byproducts are successfully used [6]. The nature and use of hardening slurries (e.g. in cut-off walls) expose them to contact with liquids of various aggressiveness degrees changing over time. Therefore, it seems important to determine the hardening slurry impact on its surrounding environment, e.g. by assessing the release of heavy metals from it, taking into account various operating conditions of the material. It is also very crucial to specify what part of metals contained in the slurry may be mobile and get into the environment.

This paper presents the test results related to the leaching of heavy metals from the hardened hardening slurry generated on the basis of the fly ash from thermal treatment of municipal sewage sludge, as well as an attempt to determine the amount of potentially mobile heavy metals contained in it.

\section{Test subject, objective and method}

\subsection{Test subject}

The test subject included the hardening slurry samples with the composition specified in Table 1. The main dry component of the hardening slurry constituted the fly ash from thermal treatment of municipal sewage sludge obtained in Pyrofluid ${ }^{\mathrm{TM}}$ technology [7]. The chemical and physical properties of the ash used in the experiment were described in the publication of Szarek and Wojtkowska [3]. The ash analyses made in the SEM technique with the use of ZEISS LEO 1430 scanning electron microscope, equipped with Oxford ISIS 300 (Oxford Instruments) energy dispersive system (EDS), were listed below. The observations of the ash microstructure from thermal treatment of municipal sewage sludge were carried out at the Polish Geological Institute - in Warsaw (tests were conducted by Leszek Giro). The samples intended for testing were dried, placed on a plate, and then sprayed with a thin layer of gold. The observations were made in low vacuum conditions $\left(6 \cdot 10^{-5} \div 7 \cdot 10^{-6}\right.$ Torr $)$, at $20 \mathrm{kV}(80 \mu \mathrm{A})$.

Table 1 Hardening slurry composition

\begin{tabular}{|c|c|}
\hline Component & The content in $\mathrm{kg} / \mathrm{m}^{3}$ of the slurry \\
\hline Tap water & 784 \\
\hline Sodium bentonite & 31 \\
\hline Fly ash from TTMSS & 353 \\
\hline Cement CEM I 32.5 R & 141 \\
\hline \multicolumn{2}{|c|}{ Heavy metal content [mg $/ \mathrm{kg} \mathrm{d.m.]}$} \\
\hline
\end{tabular}




\begin{tabular}{|c|c|c|c|}
\hline Element & CEM I 32.5R* & $\begin{array}{c}\text { Fly ash from thermal } \\
\text { treatment of municipal } \\
\text { sewage sludge* }\end{array}$ & Hardening slurry** \\
\hline $\mathrm{Cd}$ & 10.8 & 14.0 & 12.1 \\
\hline $\mathrm{Cr}$ & 64.4 & 179.2 & 134.8 \\
\hline $\mathrm{Cu}$ & 120.0 & 808.3 & 563.1 \\
\hline $\mathrm{Pb}$ & 89.7 & 56.1 & 60.6 \\
\hline $\mathrm{Zn}$ & 804.1 & 3289.9 & 2375.3 \\
\hline $\begin{array}{l}*-\text { samples were mineralised, and the content of metals was marked with the use of FAAS technique, } \\
* *-\text { calculated on the basis of the slurry composition and the content of heavy metals in its } \\
\text { components assuming that make-up water and bentonite do not bring a charge of heavy metals with } \\
\text { them }\end{array}$
\end{tabular}




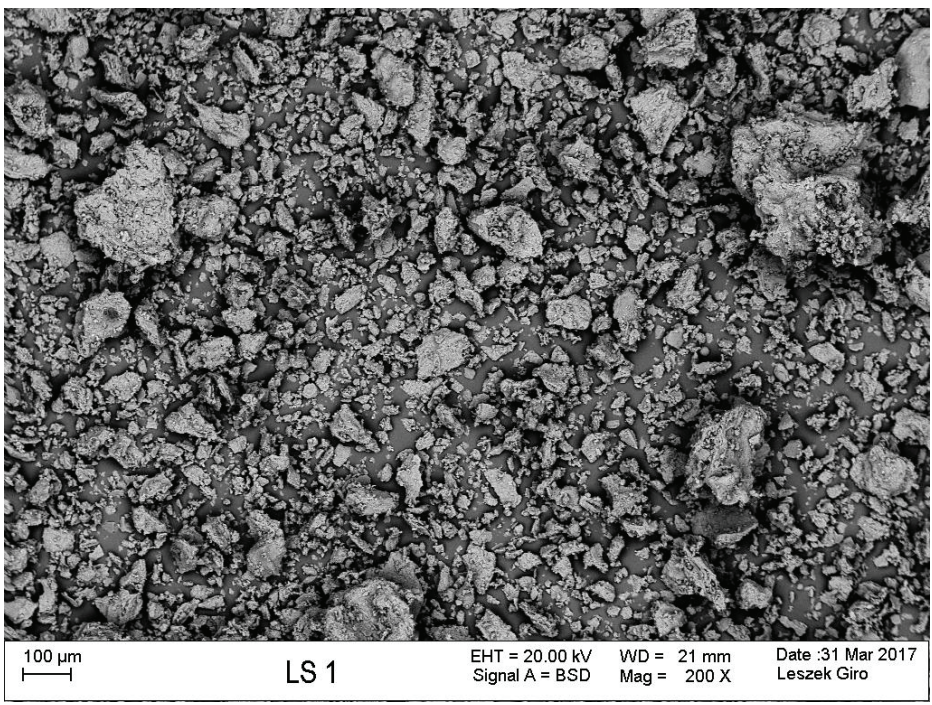

Fig. 1 Irregular ash grains from TTMSS, 200x magnification, BSD technique

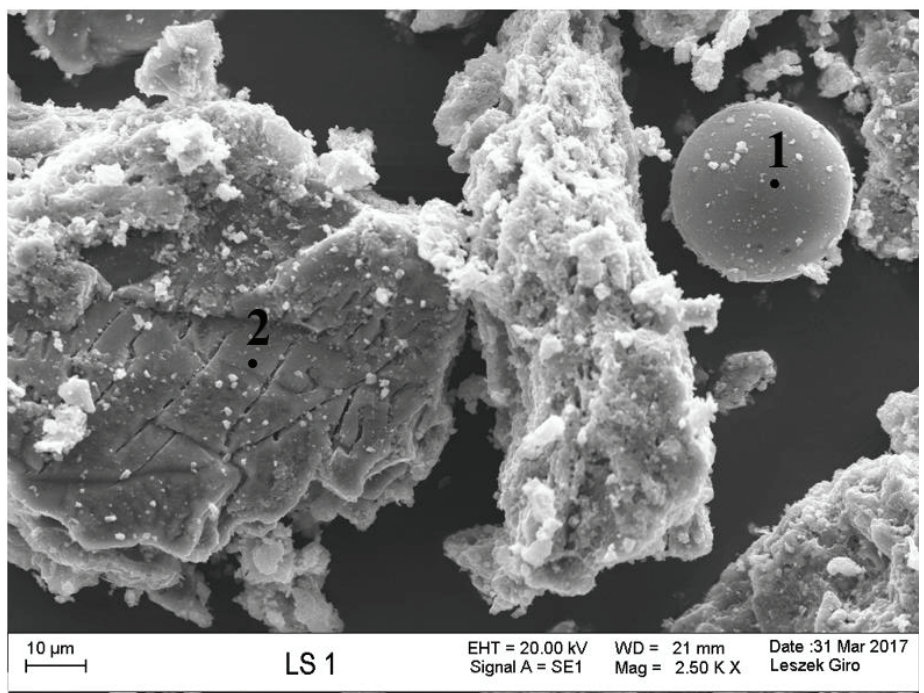

Fig. 2 Ash grains from TTMSS, 2500x magnification, SE technique

Fig. 1 presents irregular ash grains of different sizes from thermal treatment of municipal sewage sludge. The larger grains constitute clusters of many minerals. Fig. 2 presents the magnification of an irregular ash grain (area 2) in the form of silica. The picture also shows a spherical sinter (area 1) with a ball shape that is characteristic of fly ashes, which contains phosphorus compounds (Fig. 3). 

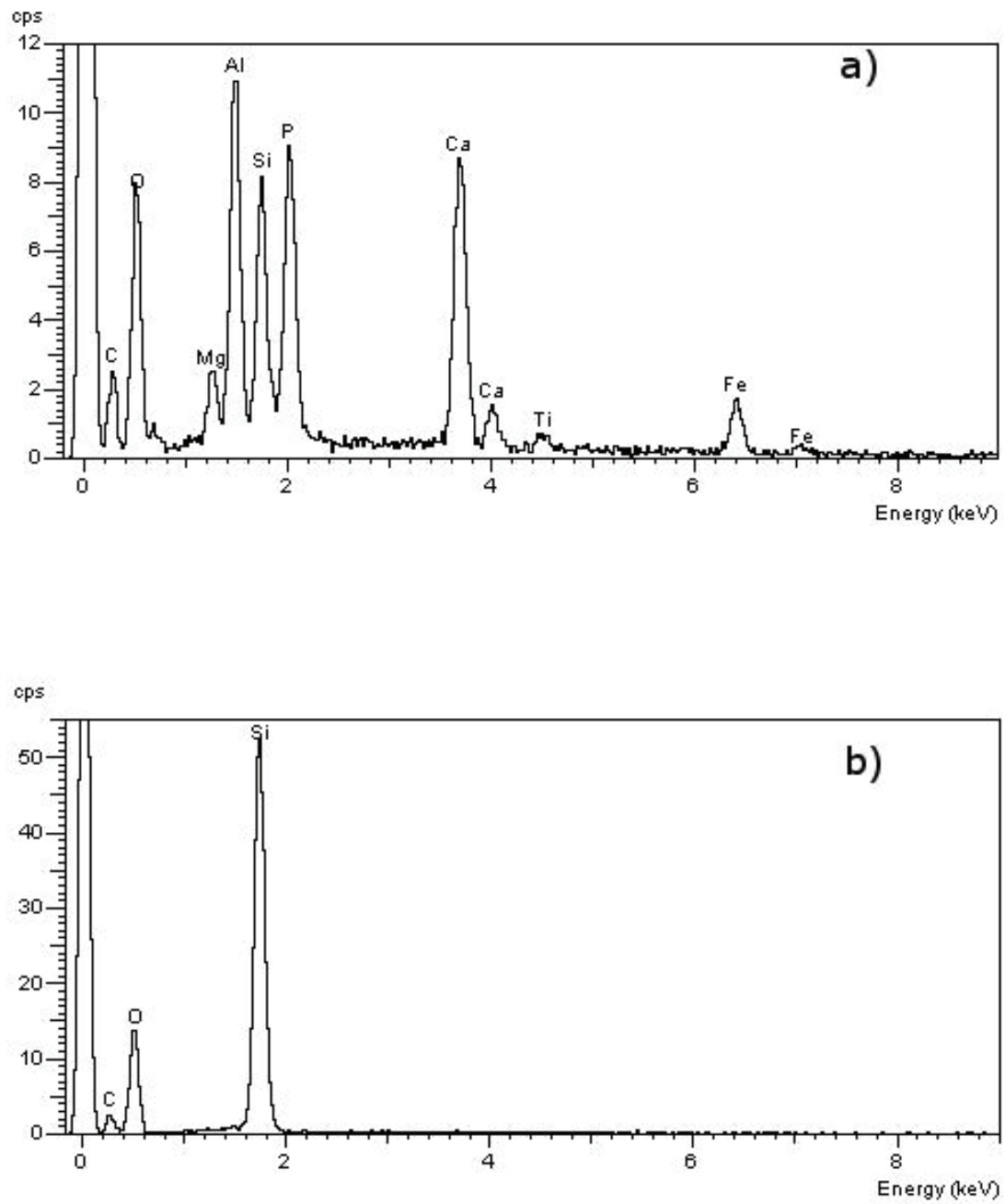

Fig. 3 EDS analysis of areas 1 (a) and 2 (b) - fig. 2

\subsection{Test objective}

The test was aimed at checking the impact of a type and reaction of the leaching liquids and the age of samples on the release of heavy metals, and also an attempt to determine the amount of potentially mobile heavy metals in the hardening slurry with the composition specified in Table 1.

\subsection{Test method for the release of heavy metals from the hardening} slurry

The eluates for determining the content of heavy metals were obtained with the use 
of a short-term, dynamic method, the socalled "batch test" [8]. The essence of this method is to subject the crushed material sample to the leaching liquid activity within 24 hours of dynamic mixing. The main assumption of the method is a thesis that during the test a state of equilibrium or a state close to the one of equilibrium between the liquid and solid phases (dry weight of the sample) is obtained. In the tests, a ratio of the liquid phase to the solid one $\mathrm{L} / \mathrm{S}=10 \mathrm{l} / 1 \mathrm{~kg}$ was applied. It results from the fact that in the tests of Mizerna and Król [9], the significantly higher (from $41 \%$ to $78 \%$ depending on the analysed metal) contents of heavy metals were observed in water extracts obtained for $\mathrm{L} / \mathrm{S}=10 \mathrm{l} / 1 \mathrm{~kg}$ ratio than for $\mathrm{L} / \mathrm{S}=21 / 1 \mathrm{~kg}$ ratio.

The hardening slurry was tested after 7 , 14 and 28 days of its curing in tap water. The hardened samples were crushed to particles of less than $10 \mathrm{~mm}$, and then (90 g d.m. of a material) covered with the appropriate volume $\left(0,778 \mathrm{dm}^{3}\right)$ of distilled water (according to [8] standard) or 0.1 molar solution of the ethylenediaminetetraacetic acid salt (0.1 molar EDTA). The $\mathrm{pH}$ of distilled water and 0.1 molar EDTA used in the experiment were respectively 7,0 and 4,5 . The leaching of heavy metals with the use of EDTA solution was aimed at determining the metal forms that reflect the potentially biological assimilability of individual metals for plants or organisms (assimilable forms) and the susceptibility of metals to leaching [10]. EDTA is a solution most commonly used in single extraction in order to predict the bioavailability of metals in calcareous soils [11]. It forms stable, mostly watersoluble, complexes with heavy metals, mobilize them from the solid phase to water [12].

The samples of the crushed slurry covered with water were subject to continuous mixing for 24 hours with the use of a roller mixer. The eluates were vacuum filtered through a hydrophobic polytetrafluoroethylene (PTFE) membrane filter with a pore diameter of $\varphi=0,45 \mu \mathrm{m}$; the filters were moistened with ethanol before use. The conductivity and $\mathrm{pH}$ of the eluate were measured immediately after filtration. In order to counteract the precipitation of compounds from the solution, the filtrates were fixed by adding approx. $1 \mathrm{ml}$ of concentrated nitric acid per $100 \mathrm{ml}$ of the filtrate, and then the content of the selected heavy metals was determined in them.

The conductivity and $\mathrm{pH}$ of the eluates were determined on Elmetron CPC-511 (Poland) device equipped with a ECF-1 conductivity cell, a IJ-44C complex electrode, and a temperature sensor.

The content of heavy metals $(\mathrm{Zn}, \mathrm{Cu}$, $\mathrm{Pb}, \mathrm{Cd}, \mathrm{Cr}$ ) was determined by an atomic absorption spectrometer with flame atomisation (Flame Atomic Absorption Spectroscopy-FAAS) on the basis of standard curves determined for a series of the previously prepared MERC standard solutions [13]. The uncertainty of the heavy metal content determination ranged from $6 \%$ to $30 \%$.

\section{Test results}

Table 2 presents the test results of the content of the selected heavy metals in the eluates obtained with the use of the "batch test" method for distilled water and 0.1 molar EDTA solution. In addition, Table 2 includes $\mathrm{pH}$ and conductivity of eluates. Based on the obtained values of the concentration of metals in the eluates, the released quantities of components, were calculated in relation to the sample dry weight.

Table 2 Properties of eluates

\begin{tabular}{|l|l|l|}
\hline Properties/ & Unit & Curing time of the slurry samples by the date of testing [days] \\
\cline { 3 - 3 }
\end{tabular}




\begin{tabular}{|c|c|c|c|c|c|c|c|}
\cline { 3 - 8 } Metal & & \multicolumn{2}{|c|}{7} & \multicolumn{2}{c|}{14} & \multicolumn{2}{c|}{28} \\
\cline { 3 - 8 } & & $\mathrm{H}_{2} \mathrm{O}_{\text {dest. }}$ & $\begin{array}{c}0.1 \text { molar } \\
\text { EDTA }\end{array}$ & $\mathrm{H}_{2} \mathrm{O}_{\text {dest. }}$ & $\begin{array}{c}0.1 \text { molar } \\
\text { EDTA }\end{array}$ & $\mathrm{H}_{2} \mathrm{O}_{\text {dest }}$ & $\begin{array}{c}0.1 \text { molar } \\
\text { EDTA }\end{array}$ \\
\hline $\mathrm{pH}$ & {$[-]$} & 11.7 & 10.8 & 11.4 & 10.1 & 11.2 & 9.5 \\
\hline $\begin{array}{c}\text { Conductivit } \\
\mathrm{y}\end{array}$ & {$[\mathrm{mS} / \mathrm{cm}]$} & 1.55 & 9.71 & 1.14 & 10.04 & 0.99 & 9.50 \\
\hline $\mathrm{Cd}$ & {$\left[\mathrm{mg} / \mathrm{dm}^{3}\right]$} & 0.011 & 0.088 & 0.011 & 0.099 & 0.012 & 0.098 \\
\hline $\mathrm{Cr}$ & {$\left[\mathrm{mg} / \mathrm{dm}^{3}\right]$} & 0.078 & 0.124 & 0.064 & 0.251 & 0.053 & 0.329 \\
\hline $\mathrm{Cu}$ & {$\left[\mathrm{mg} / \mathrm{dm}^{3}\right]$} & $<0.001$ & 2.036 & $<0.001$ & 3.776 & $<0.001$ & 3.790 \\
\hline $\mathrm{Pb}$ & $\begin{array}{c}{\left[\mathrm{mg} / \mathrm{dm}^{3}\right]} \\
\mathrm{Zn}\end{array}$ & 0.184 & 1.60 & 0.387 & 2.016 & 0.408 & 2.508 \\
\hline$\left[\mathrm{mg} / \mathrm{dm}^{3}\right]$ & 0.275 & 0.881 & 0.342 & 4.513 & 0.189 & 7.361 \\
\hline $\mathrm{Cd}$ & $\begin{array}{c}{[\mathrm{mg} / \mathrm{kg}} \\
\mathrm{d} . \mathrm{m} .]\end{array}$ & 0.11 & 0.88 & 0.11 & 0.99 & 0.12 & 0.98 \\
\hline $\mathrm{Cr}$ & $\begin{array}{c}{[\mathrm{mg} / \mathrm{kg}} \\
\mathrm{d} . \mathrm{m} .]\end{array}$ & 0.78 & 1.24 & 0.64 & 2.51 & 0.53 & 3.29 \\
\hline $\mathrm{Cu}$ & $\begin{array}{c}{[\mathrm{mg} / \mathrm{kg}} \\
\mathrm{d} . \mathrm{m} .]\end{array}$ & $<0.01$ & 20.36 & $<0.01$ & 38.78 & $<0.01$ & 37.90 \\
\hline $\mathrm{Pb}$ & $\begin{array}{c}{[\mathrm{mg} / \mathrm{kg}} \\
\text { d.m. }]\end{array}$ & 1.84 & 16.00 & 3.87 & 20.16 & 4.08 & 25.08 \\
\hline $\mathrm{Zn}$ & $\begin{array}{c}{[\mathrm{mg} / \mathrm{kg}} \\
\text { d.m. }]\end{array}$ & 2.75 & 8.81 & 3.42 & 45.13 & 1.89 & 73.61 \\
\hline
\end{tabular}

\section{Analysis and discussion of results}

\subsection{Reaction and conductivity of eluates and curing time of samples}

For eluates obtained as a result of leaching with distilled water and 0.1 molar EDTA solution, the $\mathrm{pH}$ value was decreasing along with extending the curing time of samples (Pearson's linear correlation coefficient respectively: -0.951 and $0.969)$. The conductivity values $(r=0.899)$ for distilled water are similar.

The eluate conductivity based on 0.1 molar EDTA does not show the correlation with the curing time of samples (correlation coefficient, respectively: $0.553)$.

In particular, in case of leaching with distilled water, a change in $\mathrm{pH}$ of eluates results from the binder solidification processes in the hardening slurry (which proceeded along with extending the curing time of samples) and the interaction of leaching liquids with the sample matrix.

The leached chemical compounds increase the $\mathrm{pH}$ value and conductivity of eluates. The reaction is the main factor determining the solubility of heavy metals in water.

\subsection{Release of heavy metals}

All the considered heavy metals are leached more strongly as a result of the 0.1 molar EDTA solution impact on the slurry sample (Table 2), a difference in most cases is greater by an order of magnitude. The metal forms released as an effect of leaching with 0.1 molar EDTA solution belong to potentially mobile forms, especially, when changing the environment, $\mathrm{pH}$ or a redox potential [14]. It is of particular importance in case of the 
hardening slurry contact with an trend lines were placed on the diagrams. aggressive liquid, e.g. in cut-off walls of waste landfills.

Figures 4 and 5 present the release of the selected heavy metals in relation to $\mathrm{pH}$ Due to the insufficient number of tested samples, it is not possible to verify the of the eluates and the leaching liquid. The

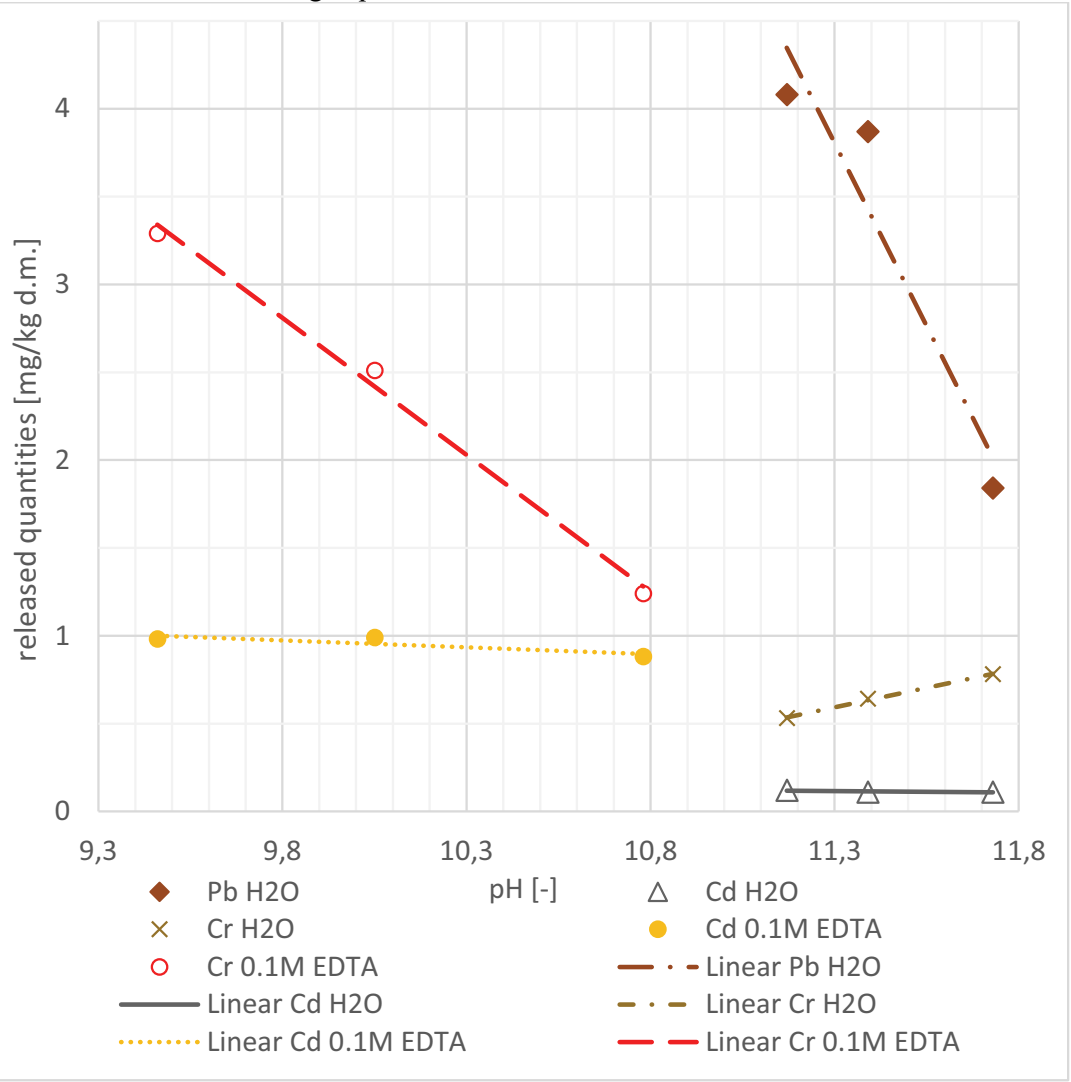

Fig. 4 Release of cadmium, chromium and lead from the hardening slurry depending on the leaching liquid and $\mathrm{pH}$ of the eluate

The obtained results of the cadmium extraction with distilled water (Fig. 4, Table 2) do not provide any grounds for determining the relationship between the release intensity and $\mathrm{pH}$ value. However, a trend of the cadmium release as a result of 0.1 molar EDTA solution activity (Fig. 4) is probably of the decreasing nature in relation to $\mathrm{pH}(\mathrm{r}=-0.867)$. By analysing the literature data [15 - 17], it is not possible to unambiguously determine the trend of changes which affects the intensity of cadmium leaching from cement-based materials in the analysed $\mathrm{pH}$ range. The type of the material [18] and its form have a strong impact on this relationship. 
The obtained results for the eluate based on distilled water (Fig. 4) show the decreasing intensity of the lead leaching with an increase in the solution acidity $(\mathrm{r}=-0.951)$. In the literature, it is possible to find similar relationships [16], as well as the opposite ones [17]. According to the authors, a complex mechanism including the interaction of cement and bentonite is responsible for the immobilization of heavy metals in the hardening slurries. For the eluates based on 0.1 molar EDTA (Fig. 5 ), the intensity of the lead leaching was lower for higher values $\mathrm{pH}(\mathrm{r}=0.994)$.

The intensity of the release of chromium (Fig. 4) as a result of distilled water $(r=0.998)$, shows a rising trend in the tested $\mathrm{pH}$ range, which is confirmed in the general relationship of anions [15]. As a result of the impact of 0.1 molar EDTA solution on samples, the results (Fig. 4) indicating the decreasing intensity of the release of chromium with an increase in $\mathrm{pH}(\mathrm{r}=0,997)$ were obtained.

In case of leaching with distilled water, the release of zinc (Fig. 5) can be probably determined as directly proportional to $\mathrm{pH}$ $(\mathrm{r}=0.455)$, which in this $\mathrm{pH}$ range can be found in other tests of Van der Sloot and Dijkstra, Van der Sloot et al. and Dijkstra et al. $[15,16,18]$. However, it is important to take into account the difference in the test subject (mortars, bottom ash, concrete).The amount of the released zinc leached by 0.1 molar EDTA decreased with an increase in $\mathrm{pH}(\mathrm{r}=-0.999)$. A similar general trend for this element in a similar $\mathrm{pH}$ range (but for a different leaching liquid), for mortars was presented by Van der Sloot and Dijkstra [15].

Copper is usually strongly immobilized by cement hydration products [19]. In the eluates obtained as a result of leaching with distilled water, the concentration of this element was below the limit of quantification for the applied method (Table 2). In case of 0.1 molar EDTA, a decreasing leaching value with an increase in $\mathrm{pH}(\mathrm{r}=-0.875)$ was found. A similar trend can be noticed (with regard to differences in the methodology) for some crushed samples of cement mortars in operation [16], however, the copper leaching intensity was significantly lower in most cases. 


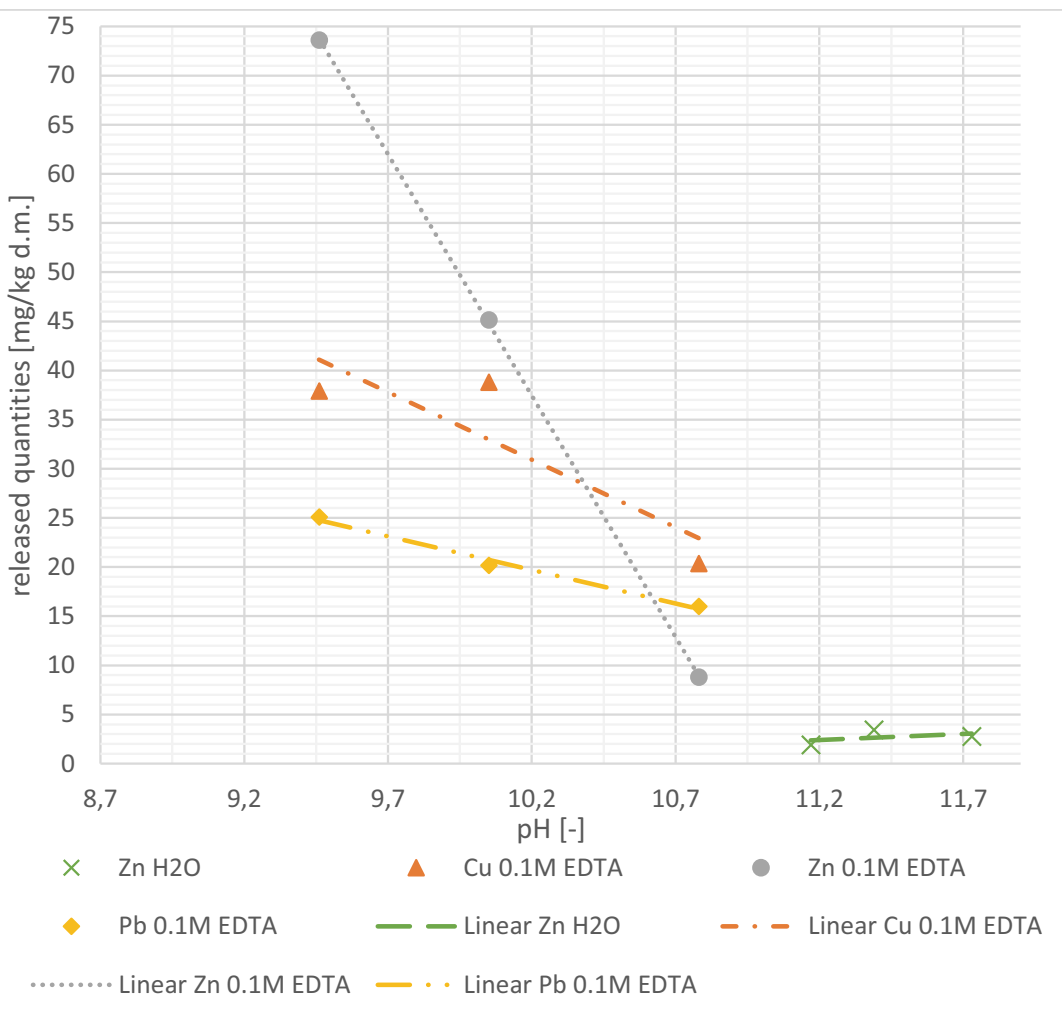

Fig. 5 Release of copper, zinc and lead from the hardening slurry depending on the leaching liquid and $\mathrm{pH}$ of the eluate

\subsection{Immobilization of heavy metals}

Degree of immobilization of heavy metals was calculated by the formula (1):

$$
I_{i}=\left(1-\frac{m_{i, e}}{m_{i, m}}\right) \cdot 100 \% \text { (1) }
$$

where $m_{i, e}$ is the mass of the i-th heavy metal in the eluate, $m_{i, m}$ is the mass of the i-th heavy metal in the tested material.

Table 3 Immobilization degree of heavy metals in the hardening slurry

\begin{tabular}{|l|c|c|c|c|}
\multicolumn{2}{c|}{ Table 3 Immobilization degree of heavy metals in the hardening slurry } \\
\hline \multirow{3}{*}{ Leaching liquid } & \multirow{2}{*}{ Heavy metal } & \multicolumn{3}{|c|}{ Slurry curing time [days] } \\
\cline { 2 - 5 } & & 7 & 14 & 28 \\
\cline { 2 - 5 } & \multicolumn{4}{|c|}{ Degree of metal immobilization [\%] } \\
\hline \multirow{2}{*}{ Distilled water } & $\mathrm{Cd}$ & 99.21 & 99.21 & 99.14 \\
\cline { 2 - 5 } & $\mathrm{Cr}$ & 99.50 & 99.59 & 99.66 \\
\hline
\end{tabular}

Table 3 presents a degree of immobilization of heavy metals in the slurry used for testing. Due to the insufficient number of samples, the statistical significance of the correlation of immobilization and the curing time cannot be verified, however, the importance of the leaching liquid is clearly visible. 


\begin{tabular}{|c|c|c|c|c|} 
& $\mathrm{Cu}$ & $>99.99$ & $>99.99$ & $>99.99$ \\
\cline { 2 - 5 } & $\mathrm{Pb}$ & 97.37 & 94.48 & 94.18 \\
\cline { 2 - 5 } & $\mathrm{Zn}$ & 99.90 & 99.88 & 99.93 \\
\hline \multirow{4}{*}{$\begin{array}{c}0.1 \text { molar EDT } \\
\mathrm{A}\end{array}$} & $\mathrm{Cd}$ & 93.69 & 92.90 & 92.97 \\
\cline { 2 - 5 } & $\mathrm{Cr}$ & 99.20 & 98.39 & 97.89 \\
\cline { 2 - 5 } & $\mathrm{Cu}$ & 96.87 & 94.05 & 94.18 \\
\cline { 2 - 5 } & $\mathrm{Pb}$ & 77.16 & 71.23 & 64.20 \\
\cline { 2 - 5 } & $\mathrm{Zn}$ & 99.68 & 98.36 & 97.32 \\
\hline
\end{tabular}

The degree of the cadmium immobilization may be considered constant regardless of the curing time of the sample and leaching liquid.

The degree of the chromium immobilization during leaching with distilled water was increasing with the sample curing period $(r=0.966)$, however, for the samples leached with 0.1 molar EDTA solution, it was decreasing $(r=-0.947)$.

The degree of the copper immobilization during leaching with distilled water does not depend on the curing time and it can be considered complete. In case of leaching with 0.1 molar EDTA solution, it can be considered constant.

The degree of the lead immobilization was decreasing with the curing time (decreasing $\mathrm{pH}$ - Table 2) regardless of the leaching liquid type (correlation coefficient of $-0,809$ for distilled water, and $-0,990$ for 0.1 molar EDTA). The similar relation of leaching the heavy metals from the hardening slurries was obtained with the use of a hydrochloric acid solution in the work of Kledyński et al. [20], as well as with the use of distilled water, which was shown in the tests of Wojtkowska et al. [5], however, in the cited work [5], a different method for the implementation of water extracts was used. The opposite trends were described by Król [19], however, in the cited work, the mortars with an additive of heavy metal salts, which were leached with the liquid at $\mathrm{pH}$ of 7 , were subjected to tests.
The degree of the zinc immobilization in the hardening slurry in case of leaching with distilled water should be considered high, regardless of the test time. For 0.1 molar EDTA, the immobilization degree decreases with the curing time extension $(r=-0.945)$.

\section{Conclusion}

1. The conducted tests confirmed the impact of a type of the leaching liquid, $\mathrm{pH}$, and the curing time of samples on the leaching intensity and the degree of immobilization of heavy metals contained in the hardening slurry. When using EDTA solution as a leaching liquid, the susceptibility of metals to leaching increases significantly. It indicates the need to consider the intensity of the release of heavy metals for building materials in the context of the environment, in which they operate.

2. In case of leaching with distilled water, the strong immobilization for four analysed metals, except for lead, was obtained. The lowest level of immobilization (reaching only 64.20\%) was found for lead when leaching with 0.1 molar EDTA solution.

3. In case of the lead immobilization, the experiment results presented in the paper are consistent with the results obtained for the hardening slurries in the works of Wojtkowska et al. [5] and Kledyński et al.[20], however, they differ from Król's test results [19], 
yet they were related to other cementbased materials. According to the authors, a complex mechanism, including the interaction of cement and bentonite, is responsible for the immobilization of heavy metals in the hardening slurries, and therefore, the immobilization of heavy metals in the matrix may take place in a different way than in other cement-based materials.

4. It should be noted that in case of leaching with distilled water, it is not possible to determine the amount of the released potentially bioavailable heavy metal forms, which in case of hardening slurries are important in view of the slurry contact with ground water of varying degrees of aggressiveness.

5. It is proposed to conduct further tests on the leaching of heavy metals from hardening slurries, including the speciation of elements, e.g. by adopting the method for sequential extraction for seabed sediments [21], taking into account the difference of materials.

\section{References}

1. Główny Urząd Statystyczny. Ochrona Środowiska 2015. (2015)

2. Falacinski, P., Szarek, Ł., Possible applications of hardening slurries with fly ash from thermal treatment of municipal sewage sludge in environmental protection structures. Archives of Hydro-Engineering and Environmental Mechanics. 63(1), pp. 47-61, (2016)

3. Szarek, Ł., Wojtkowska, M. Properties of fly ash from thermal treatment of municipal sewage sludge in terms of EN 450-1. Archives of Environmental Protection, Vol. 44 no. 1 pp. $62-68$ (2018).

4. Łukawska, M., Speciation analysis of phosphorus in sewage sludge after thermal utilization of sludge. Inżynieria i Ochrona Środowiska. 17(3), pp. 433-439. (2014).
5. Wojtkowska, M., Falaciński, P., Kosiorek, A., The release of heavy metals from hardening slurries with addition of selected combustion byproducts. Inżynieria i Ochrona Środowiska. 19(4), pp. 479-491. (2016).

6. Kledyński, Z., Rafalski, L., Zawiesiny twardniejace. Komitet Inżynierii Lądowej i Wodnej PAN, Warsaw. (2009).

7. MPWiK

https://www.mpwik.com.pl/view/ter miczne-przeksztalcanie-osadow (18.12.2017).

8. EN 12457-4:2002 Characterisation of waste - Leaching - Compatibility test on leaching of granular waste materials and sludges. Part 4: Singlestage batch testing with a ratio of the liquid to $101 / \mathrm{kg}$ solid phase in case of materials with particle sizes of less than $10 \mathrm{~mm}$ (with or without the size reduction). (2002).

9. Mizerna, K., \& Król, A. Wptyw wybranych czynników na wymywalność metali ciężkich $z$ odpadu hutniczego. Inżynieria Ekologiczna. (2015).

10. Karczewska A. Metale ciężkie w glebach zanieczyszczonych emisjami hut miedzi - formy i rozpuszczalność. Zeszyty Naukowe Akademii Rolniczej we Wrocławiu, 432, pp. 1159. (2002).

11. Alvarez, J. M., Lopez-Valdivia, L. M., Novillo, J., Obrador, A., Rico, M. I. Comparison of EDTA and sequential extraction tests for phytoavailability prediction of manganese and zinc in agricultural alkaline soils. Geoderma. 132(3). pp. 450-463. (2006).

12. Li, Z., Shuman, L. M. Redistribution of forms of zinc, cadmium and nickel in soils treated with EDTA. Science of the Total Environment. 191(1). pp. 95-107. (1996).

13. EN ISO $15586: 2003$ Water quality Determination of trace elements 
using atomic absorption spectrometry with a graphite furnace (2003).

14. Wojtkowska, M. Rola specjacji $w$ ocenie mobilności metali ciężkich $w$ płynacych wodach powierzchniowych. Prace Naukowe Politechniki Warszawskiej. Inżynieria Środowiska. (62). pp. 3119. (2013).

15. Van der Sloot, H. A., Dijkstra, J. J. Development of horizontally standardized leaching tests for construction materials: a material based or release based approach? Identical leaching mechanisms for different materials. Energy Research Centre of the Netherlands, Report No. ECN-C-04-060, 44 pp. \& annexes. (2004).

16. Van der Sloot, H. A., Van Zomeren, A., Meeussen, J. C. L., Hoede, D., Rietra, R. P. J. J., Stenger, R., Lerat, A. Environmental Criteria for Cement Based Products Phase I : Ordinary Portland Cement Phase II : Blended Cements and methodology for impact assessment. Energy Research Centre of the Netherlands, Report No. ECN-E--11-020, 136pp. $\&$ annexes.( 2011).

17. Dijkstra, J. J., Van der Sloot, H. A., Spanka, G., Thielen, G., How to judge release of dangerous substances from construction products to soil and groundwater. ECNC-05-045. (2005).

18. Dijkstra, J. J., Van der Sloot, H. A., Comans, R. N., The leaching of major and trace elements from MSWI bottom ash as a function of $\mathrm{pH}$ and time. Applied Geochemistry. 21(2), pp. 335-351. (2006).

19. Król, A., Uwalnianie metali ciężkich $z$ kompozytów mineralnych $z$ uwzględnieniem oddziatywania środowiska]. Wydawnictwo Politechniki Opolskiej, Opole. (2012).

20. Kledyński, Z., Wojtkowska, M., Falaciński, P., Szarek, Ł.
Immobilizacja metali ciężkich w zawiesinach twardniejacych $z$ popiolami $z \quad$ termicznego przeksztatcania komunalnych osadów ściekowych $w$ świetle dynamicznych badań krótkoterminowych. Prace Instytutu Ceramiki i Materiałów Budowlanych No. 30. pp. 79-93. (2018).

21. Tessier, A., Campbell, P. G., \& Bisson, M. Sequential extraction procedure for the speciation of particulate trace metals. Analytical chemistry. 51(7). pp. 844-851. (1979). 
Streszczenie. Rosnąca liczba oczyszczalni ścieków komunalnych w Polsce, pożądanych $\mathrm{z}$ ekologicznego punktu widzenia, rodzi problem zagospodarowania rosnącej ilości osadów ściekowych. Metoda termicznego przekształcania osadów ściekowych, znacznie redukując objętość odpadu, powoduje wzrost koncentracji metali ciężkich w żużlach i popiołach - produktach końcowych procesu przekształcania. Poszukiwania metod utylizacji popiołu lotnego z TPKOŚ zaowocowały próbami wykorzystania go $\mathrm{w}$ zawiesinach twardniejących szeroko wykorzystywanych w budownictwie hydrotechnicznym, w realizacji przesłon przeciwfiltracyjnych. Ze względu na charakter pracy tego materiału w przesłonie (ekspozycja na przepływ filtracyjny wód gruntowych) jedną z kluczowych kwestii jest stopień związania $\mathrm{W}$ nim metali ciężkich. W pracy podjęto próbę określenia stopnia uwalniania wybranych metali ciężkich $\mathrm{z}$ matrycy stwardniałej zawiesiny twardniejącej, skomponowanej z cementu, bentonitu oraz popiołu lotnego z TPKOŚ. W tym celu pobrano eluaty $\mathrm{z}$ próbek, po różnym okresie ich dojrzewania, wykorzystując dynamiczną metodę krótkoterminową, tzw. „batch test”. Jako ciecz wymywającą wykorzystano: wodę destylowaną oraz 0,1 molowy roztwór EDTA - w celu określenia potencjalnie mobilnych form metali ciężkich. Uzyskane wyniki wskazują na możliwość bezpiecznego zastosowania popiołu lotnego z TPKOŚ, jako dodatku do zawiesin twardniejących. 